\title{
From Conservation to Sustainable Development-A Case Study of Angkor World Heritage Site, Cambodia
}

\author{
Hang Peou ${ }^{1}$, Ishwaran Natarajan ${ }^{2}$, Hong Tianhua ${ }^{2}$ and Delanghe Philippe ${ }^{3}$ \\ 1. APSARA National Authority, Ampil Commune, Siem Reap, Cambodia \\ 2. International Centre on Space Technologies for Natural and Cultural Heritage (HIST) under the Auspices of UNESCO, Institute \\ of Remote Sensing and Digital Earth (RADI), Beijing 100094, China \\ 3. UNESCO Office in Phnom Penh, National Office to Cambodia, Phnom Penh 29, Cambodia
}

\begin{abstract}
The World Heritage Committee of UNESCO has called for a strategic commitment from its States Parties to strengthen links between heritage conservation and sustainable development. Fulfilment of this commitment will require integration of the conservation of sites with the sustainable use and management of natural resources in a larger area beyond the boundaries of sites. Identification and demarcation of areas for conserving World Heritage sites and sustainable development of broader regions must derive from an in-depth knowledge of people-environment relationships. The management of Angkor-an iconic World Heritage site -has been primarily focused on conservation and restoration of monuments within the boundaries of the site. However, that focus is now shifting towards addressing environmental, social and economic challenges for sustainable development of the broader landscape described in this paper as the Angkor ecosystem. Angkor has the potential to demonstrate the application of an ecosystem approach to sustainable development—advocated under the UN Convention on Biological Diversity. The site could be a laboratory for new research on cultural ecosystem services as a tool for bridging site conservation to the sustainable development of the Siem Reap province where the site is located.
\end{abstract}

Key words: Heritage, ecosystem, tourism, sustainable development.

\section{Introduction}

The Convention Concerning the Protection of the World Cultural and Natural Heritage [1] (hereafter "the Convention") is dedicated to the conservation of cultural and natural places of Outstanding Universal Value (OUV). The 21-member, World Heritage Committee (hereafter "the Committee") decides whether or not places nominated by States meet criteria and conditions for satisfying and safeguarding OUVs and merit inclusion in the World Heritage List (hereafter "the List") [2]. At the time of this writing, the List counts 1,031 properties of which 802 are cultural, 197 natural and 32 mixed sites, respectively. They span across 163 states. Mixed properties are those that meet criteria and conditions for conserving

Corresponding author: Ishwaran Natarajan, Ph.D., research fields: international dimensions of climate change and sustainable development. both cultural and natural OUVs.

Sustainable development captured the imagination of world leaders following the publication of the Report of the World Commission on Environment and Development [3]. The concept became integral to international development co-operation with the adoption of Agenda 21 by the UN Conference on Environment and Development (UNCED) held in 1992 in Rio de Janeiro, Brazil. Since then, the understanding of the concept of sustainable development and its implications for harmonizing heritage conservation and economic growth has evolved. At the Rio +10 summit held in 2002 in Johannesburg, South Africa, the international community of nations agreed that sustainable development must find a balance between economic, environmental and social trajectories of change. Support for these "three pillars" as necessary anchors 
of sustainable development has been consolidated during and after the Rio +20 Summit, convened in Rio de Janeiro, Brazil, in June 2012.

Originating 20 years before the international consensus on sustainable development, the Convention makes little reference to the latter. A search of the latest version of the Operational Guidelines for the Implementation of the Convention revealed only 4 instances of reference to sustainable development [2]. The first two are in section 1B, paragraph 6 of the Guidelines which note that the international community has embraced the concept of sustainable development since the adoption of the Convention in 1972 and insist that "the protection and conservation of the natural and cultural heritage are a significant contribution to sustainable development". The other two instances, in Section III.5 and in annex 5 , respectively, invite states to integrate sustainable development principles into the management plan for properties nominated for inclusion in the List. Awareness of the need to build mutually beneficial relationships between heritage conservation and sustainable development has grown stronger in the new millennium and permeated discussions convened to mark the commemoration of the 40th anniversary of the Convention in 2012 [4]. During the same year the Rio +20 Summit collated 20 years of lessons learnt to implement sustainable development and adopted "The Future We Want", firmly placing principles and practice of sustainable development at the centre of early $21 \mathrm{st}$ century international relations agenda. More recently, in September 2015, the UN adopted 17 Sustainable Development Goals (SDGs) covering a wide range of environmental and development sectors [5].

In this paper, sustainable development of the Angkor ecosystem which includes the World Heritage site but is defined by the boundaries of the watersheds of the three main rivers that are critical to the hydraulics of Angkor monuments and heritage (Fig. 1) is explored. Past knowledge and new information becoming available via a number of on-going projects have been used in highlighting the significance of sustainable development of the Angkor ecosystem as an important learning experiment.

\section{Watersheds}

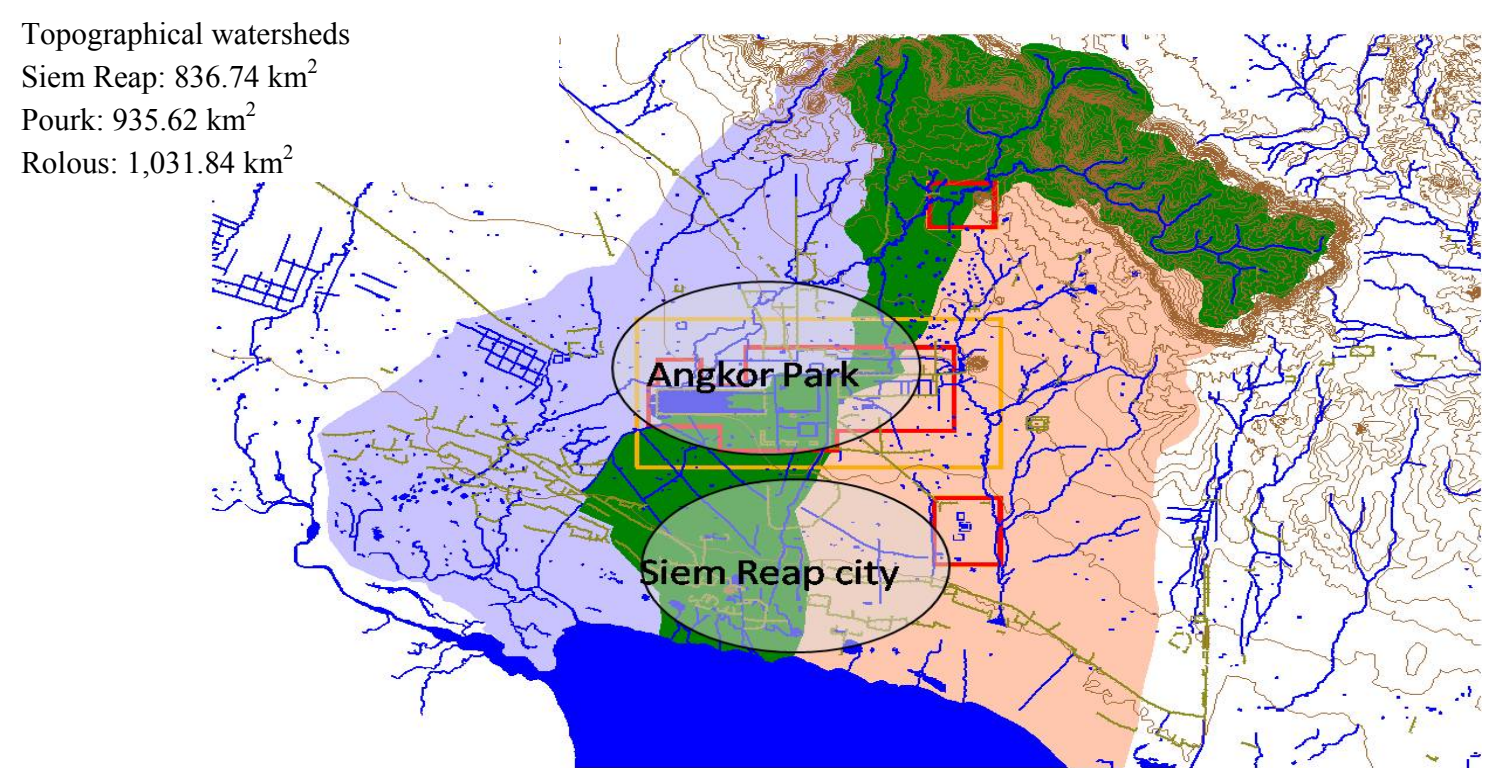

Fig. 1 The Angkor ecosystem including the World Heritage site comprising the Angor Wat (central rectangle), Bantei Srey (square north of Angkor Wat) and Rolous (square south of Angkor Wat), the three watersheds that are central to Angkor hydraulics, and the modern Siem Reap city that has developed south of the Angkor World Heritage site. 
Initially, the context and process of inscription of Angkor as a World Heritage site is described. Next, information on the efforts of the Cambodian authority responsible for the management of Angkor, namely APSARA, to integrate site conservation into sustainable use of water, forests and biodiversity as well as the interests of visitors to and residents within the Angkor ecosystem is provided. Institutional challenges facing the sustainable development of the Angkor ecosystem over the next decade are highlighted. Articulation of research on tourism and hospitality within a framework of cultural ecosystem services is encouraged. An ecosystem approach to the management and sustainable development of Angkor is likely to re-open debates on the extension of the boundaries of the World Heritage site since many important components of the historical Angkor civilization remain outside the current boundaries of the site. Focusing on the Angkor ecosystem as the unit for sustainable development will increase nature-culture synergies in the conservation of Angkor and the implementation of the Convention in Cambodia [6].

\section{Angkor World Heritage}

The fact that Angkor contains OUV of significance to humankind has rarely been in doubt. Yet when the Committee inscribed the site on the List in 1992, it had to waive some conditions for normal inscription of sites. Such a waiver was justified given the importance of Angkor to humanity's common heritage, the high risk at that time that in the absence of World Heritage status, the site's integrity and the authenticity of monuments would further deteriorate and the urgent need for coordinating international support for Angkor to address the most critical needs for safeguarding the site. At the time of inscription of Angkor on the List, Cambodia was still recovering from long years of war. The Committee declared Angkor as World Heritage in Danger, at the same time, it included Angkor in the list in 1992 and called for a range of remedial measures to ensure the protection and conservation of monuments within the area designated as World Heritage [7].

Angkor's World Heritage status is justified on criteria (i-iv) [2]. Together, these four criteria recognize the artistic and architectural masterpieces that are unique to the site and the site's historical links to the Indian sub-continent and the influences it had on political and cultural development of Southeast Asia. Nature-culture linkages in the evolution of Angkor that had attracted interests of other heritage experts a decade earlier were however, not considered during the urgency to nominate Angkor as World Heritage in 1991. The International Union of Conservation of Nature and Natural Resources (IUCN, currently known as The World Conservation Union), which is the advisory body to the Committee on natural heritage matters had included the Angkor Wat National Park in its list of the World's Greatest Natural Areas [8]. It was compiled to enable the UNESCO Secretariat and the Committee to identify natural and mixed sites that may merit inclusion in the List. On Angkor Wat National Park, IUCN observed:

"While the main attraction of this national park is the incomparable complex of great temples from the Angkor Wat civilization, the wildlife of the 10,000 ha site is also significant, including endangered species such as banteng, Eld's deer, tiger, Siamese fresh-water crocodile and a wide range of others. It also shows the typical habitat in which one of the world's great civilizations evolved, along with the wildlife which co-existed with the mighty cities. Some of the stone carvings show large concentrations of Elephants, abundant fish in the Great Lake and the now nearly extinct Kouprey (the world's rarest bovine). Criteria (ii) plus cultural criteria."

The criterion (ii) referred to by IUCN, refers to natural heritage criterion (ii) which according to the Operational Guidelines for the Implementation of the Convention of that time was defined as [9]:

“... outstanding, examples representing significant 
ongoing geological processes, biological evolution and man's interaction with his natural environment: as distinct from the periods of the earth's development, this focuses upon on-going processes in the development of communities, plants and animals, landforms and marine and fresh water bodies."

The relationship between humans and their natural environments and outstanding universal values of resulting land and seascapes for the implementation of the Convention are themes of continuing debate. Since 1996, those debates have led to significant amendments to the criteria for inclusion of natural and cultural heritage properties in the List [10-12]. Natural heritage criterion (ii) which IUCN considered applicable to the Angkor Wat National Park of 1982 has been significantly amended and its contents are partly spread across World Heritage criteria (viii) and (ix) of today [2]:

(viii)... outstanding examples representing major stages of earth's history, including the record of life, significant on-going geological processes in the development of landforms, or significant geomorphic or physiographic features;

(ix)... outstanding examples representing significant on-going ecological and biological processes in the evolution and development of terrestrial, fresh water, coastal and marine ecosystems and communities of plants and animals.

Reference to "man's interaction with his natural environment" in natural criterion (ii) of 1982 used by IUCN to justify its recommendation of the Angkor Wat National Park as a potential mixed World Heritage site no longer exists in that form in any of the World Heritage criteria. However, at present, World Heritage criteria (v) recognizes the importance of "human interaction with the environment" as:

(v)... outstanding example of a traditional human settlement, land-use or sea-use which is representative of a culture (or cultures), or human interaction with the environment especially when it has become vulnerable under the impact of irreversible change.
These changes to the definitions of criteria and their related conditions of integrity and authenticity have resulted in many cultural landscapes being declared World Heritage. They meet criterion (v) above and represent the "combined works of nature and man" described by article 1 of the Convention. Efforts and findings described in the following sections of this paper illustrate that the Angkor ecosystem is an on-going example of "human interaction with the environment". In shifting its management focus from the conservation of monuments and artefacts within the site to the sustainable development of the larger Angkor ecosystem, APSARA is striving to re-invent and sustain "nature-culture" synergies that have been central to that ecosystem for well over a millenium. The challenges of meeting Angkor's contribution to socio-economic expansion and growth at national, provincial and local levels, particularly through the development of the tourism and hospitality sector in and around the World Heritage site are reaching scales never experienced at any time during the proud history of the Khemer people. These challenges and APSARA efforts to address them are making Angkor an important learning experiment for demonstrating an ecosystem approach to sustainable development.

\section{Water-Key to a Sustainable Angkor Ecosystem}

The Angkor ecosystem is defined by Kulen mountains in the north and Tonle Sap Lake in the south (Fig. 1). The latter, often referred to as the "Great Lake" is the largest freshwater lake in southeast Asia. The east-west spread of $2,804.2 \mathrm{~km}^{2}$ is demarcated by the watersheds of the Pourk, Siem Reap and Rolous rivers. Pourk and Rolous are natural rivers. Siem Reap is an artificial water-way, receiving water from Pourk via the Bampenh reach, a $60 \mathrm{~m}$ wide, $300 \mathrm{~m}$ long laterite channel constructed in the 9th century A.D. [13]. Pourk watershed was about 1,652 $\mathrm{km}^{2}$. But since its diversion the Siem Reap watershed, 
overlapping that of Pourk, captures a significant portion of the water from Kulen that would have otherwise drained into the latter river. The water diversion appears to have been intended to fill one or more of the reservoirs east of the current World Heritage site [14]. From its earliest days, the Angkor ecosystem has witnessed human tinkering of water resources to meet Khemer civilization's utilitarian, ritual and spiritual needs.

The three-zone scheme described in some previous studies is applicable to the Angkor ecosystem (Fig. 2) $[14,15]$. A significant part of the drainage zone includes the fluctuating area seasonally inundated by the lake. The area of Tonle Sap rises from $3,500 \mathrm{~km}^{2}$ in the dry to $14,500 \mathrm{~km}^{2}$ in the wet season [14]. During Angkorean times, this massive fluctuation in water levels exposed lands that were productively used for agriculture. The situation today is different. The Siem Reap city (town) and its environs where tourism and hospitality sector infrastructure and facilities are concentrated are in the drainage zone (compare Figs. 1 and 2), and are susceptible to flooding during annual rains from May to September. Tourism to Angkor is a major contributor to the economy of the province and the nation. Flooding of Siem Reap city can cause significant loss to the economy and threaten livelihoods of people. The emergence of this city as the international visitor hub for tourists to Angkor has triggered significant changes to the landscape around it. The construction of an international airport in Siem Reap in 2004 accelerated urbanization in and around the city (Fig. 3). The demographics of the Angkor ecosystem today resembles that of other World Heritage sites like Galapagos (Ecuador) and Venice (Italy) where visitors per year clearly outnumber residents; the 2012 figures for Angkor being 2 million and 300,000, respectively. Increase in resident population in the area will continue as people from other parts of the country move-in seeking employment and entrepreneurial opportunities generated by the tourism and hospitality sector. A growing local and regional economy raises land values attracting both investors and speculators.

As the management of the Angkor ecosystem increasingly emphasizes sustainable development, upgrading and managing the Angkor hydraulics has become a central concern (Fig. 4) of APSARA. Water from the Kulen mountain flowing via the three rivers (Fig. 1) into the Great Lake has long been diverted and managed for agriculture, maintenance of water bodies in temples and monuments and perhaps flood control [15]. However, more than 8-years of APSARA research on Angkor hydraulics has not unearthed any scriptural Khmer reference to major flood or drought events, neither do Khmer people remember or recite legends and stories of such events [13]. But others [16] have argued that decades-long droughts interspersed with intense monsoons probably caused the demise of Angkor during 14th and 15th centuries. Military, political, religious and trade related changes were also contributory to the fall of Angkor [17-19]. More research on how these different factors interacted with one another, particularly from 12 th to 14 th centuries, to trigger the gradual decline and the ultimate fall of the Khmer empire is urgently needed.

APSARA has identified key water-holding and transporting infrastructure of the Angkor ecosystem (Fig. 5) [20]. Many of the findings of APSARA have recently been confirmed and further expanded by LiDAR surveys [21]. APSARA has invested considerable resources to rehabilitate these structures and increase their water holding capacities. The most important water-storage features that have been restored during 2004-2012 are:

Reservoirs or "Barays": these are the largest water-holding structures (Fig. 5). Of the four Barays, the North and Lolei Barays can hold, at full capacity, 5 Million cubic meters $\left(\mathrm{M} \mathrm{m}^{3}\right)$ and 10 Million cubic meters $\left(\mathrm{M} \mathrm{m}^{3}\right)$ of water, respectively.

The west $\left(56 \mathrm{M} \mathrm{m}^{3}\right)$ and east $\left(36 \mathrm{M} \mathrm{m}^{3}\right)$ "Barays" are capable of holding even larger volumes of water. Both 


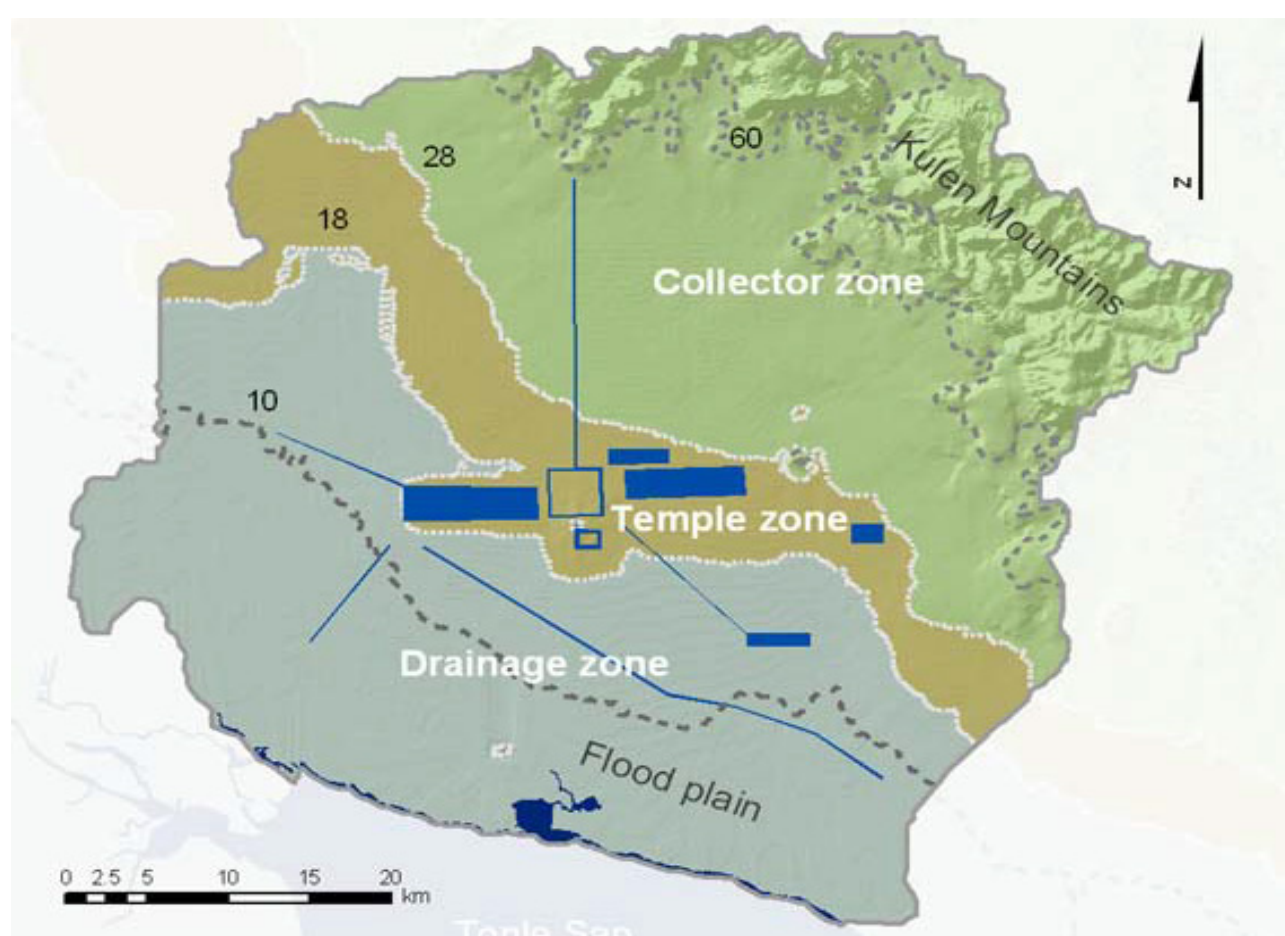

Fig. 2 Collector, temple and the drainage zones of the watersheds of the Pourk, Siem Reap and Rolous rivers [14, 15].

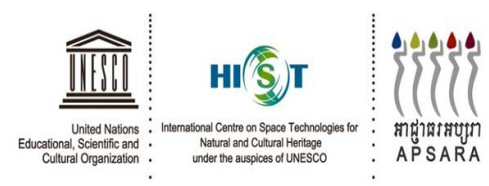

Urban Change analysis
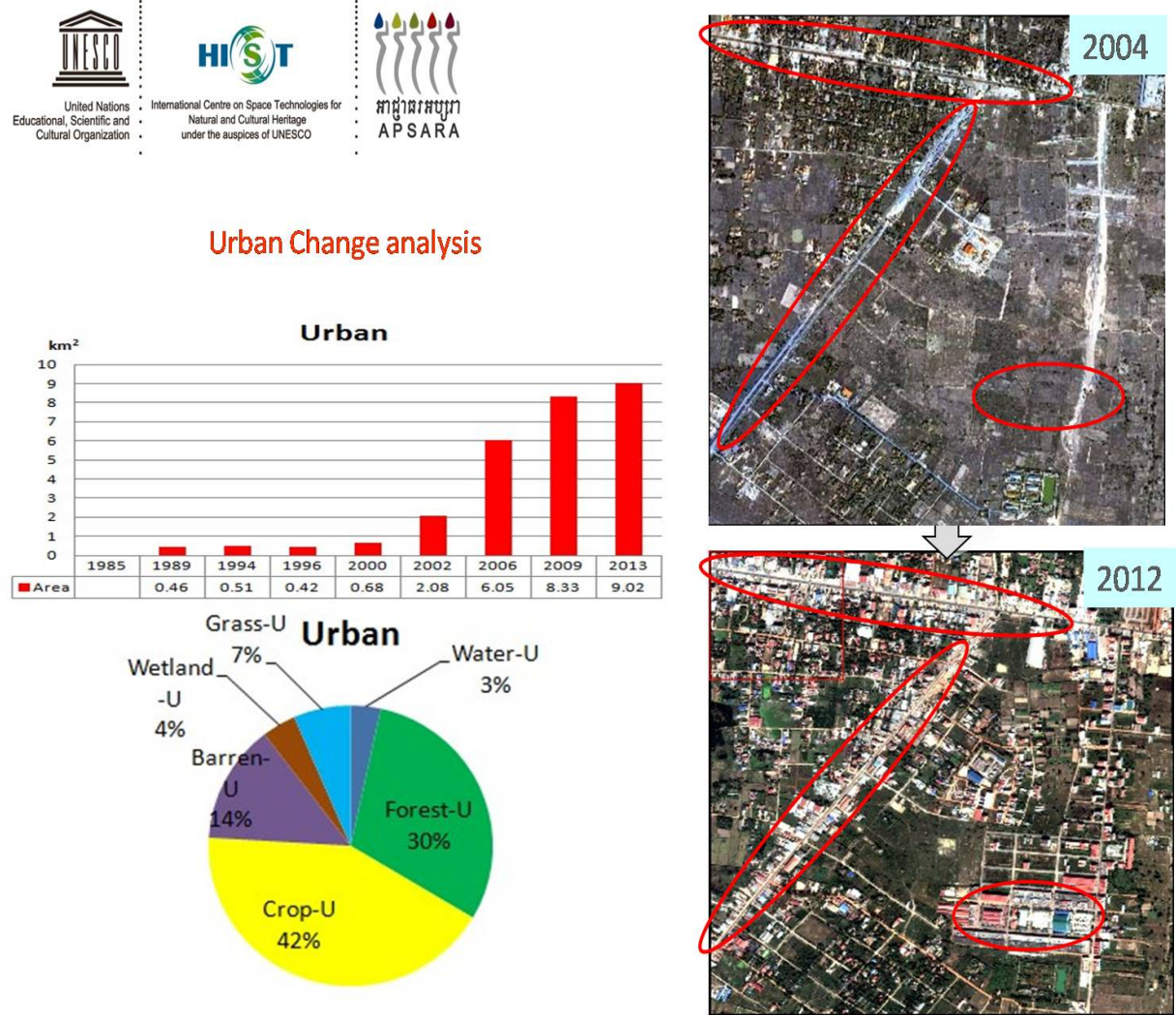

Fig. 3 Satellite images from 2004 and 2012 on the right-side of the figure show the rapid spread of urbanization in and around the Siem Reap city; the graph and the pie chart on the left show overall rates of urbanization and percentages of habitats converted to urban use, respectively, in a $138 \mathbf{~ k m}^{2}$ area including the city and its immediate environs based on time-series analyses of satellite images from 1989 to 2013. 


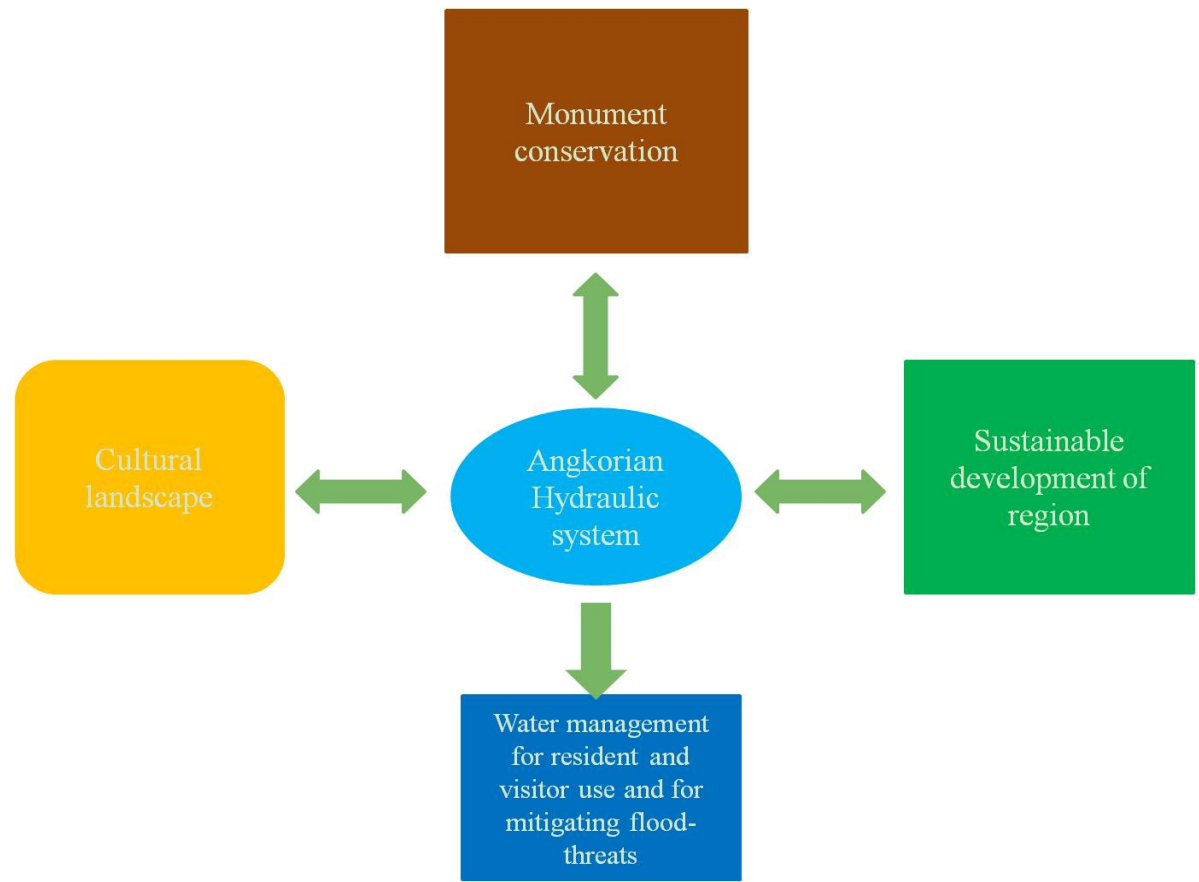

Fig. 4 The Angkorean hydraulics has now been assigned a central role for the conservation of Angkor World Heritage site and the sustainable development of the Siem Reap province.

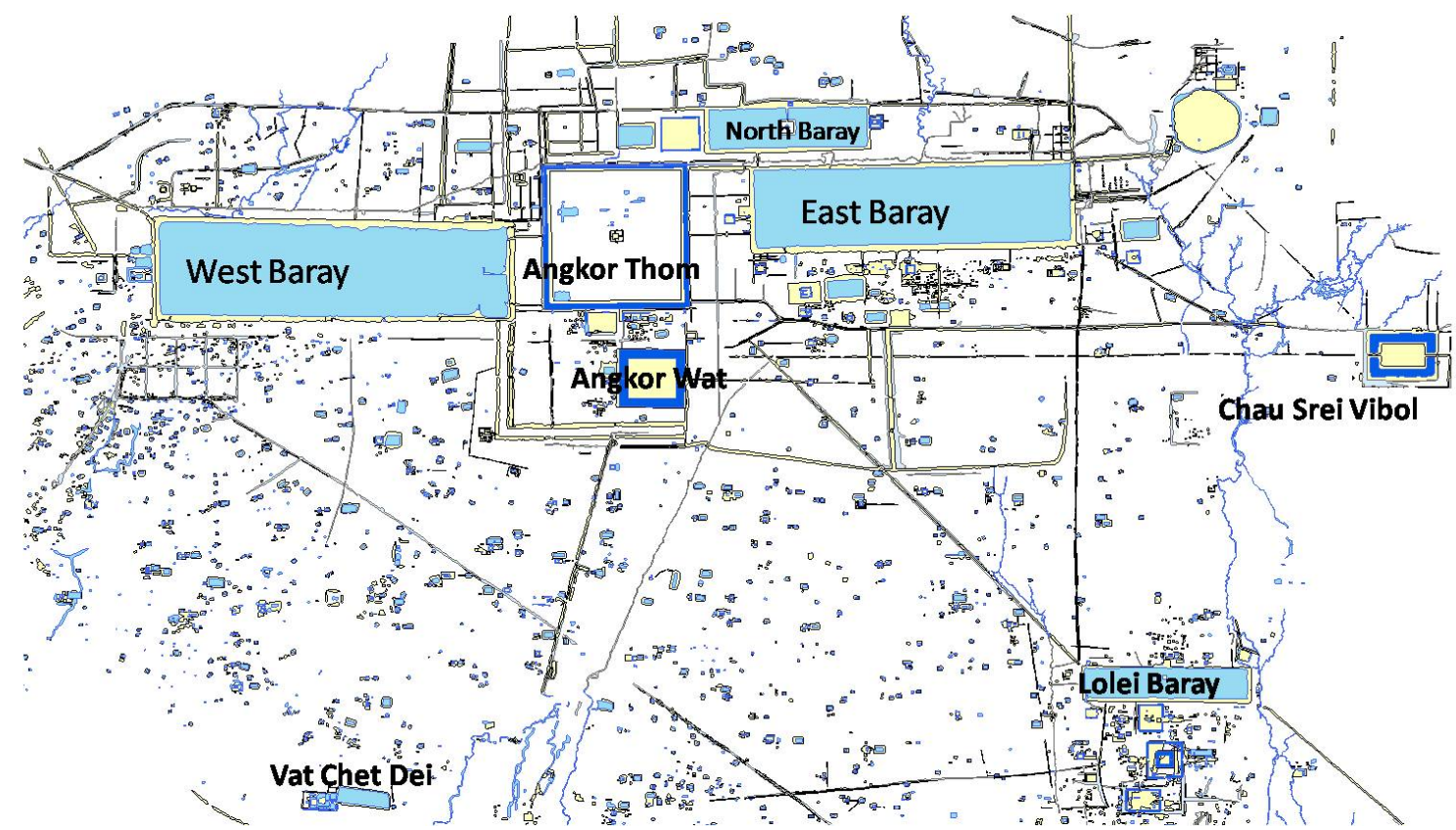

Fig. 5 The larger water holding "Barays" and moats which have been referred to in the text describing the hydraulics of the Angkor ecosystem, the figure also shows numerous other water-holding structures of various sizes distributed throughout the ecosystem [20].

north and the west "Barays" have been fully restored and the restoration of the other two is well underway.

Moats: the primary function of moats of temples in the Angkor World Heritage site was long thought to be the protection of temple interiors from outside forces. But, APSARA studies have shown that water in the moats is integral to the management of water flow and storage throughout the whole system. The larger moats of Angkor Wat and Angkor Thom temples can hold $1.5 \mathrm{M} \mathrm{m}^{3}$ and $2 \mathrm{M} \mathrm{m}^{3}$ at full capacity, 
respectively. In temples such as Bantey Srei and Preah Khan, moats that hold smaller volumes of water occur.

Ponds, royal basin and smaller water-holding structures: These abound in many temples: the royal basin of Srah Srang, the five basins within the Neak Pean temple located in the middle of the north "Baray" etc.. They can all hold smaller yet important volumes of water.

As APSARA has set about reclaiming some of the Barays, many of the smaller ponds and basins benefit. For example, the north Baray dried up 500 years ago and international teams had given up any hope of ever restoring it. In 2005, APSARA and Cambodian engineers succeeded in restoring the dyke and water returned to the Baray in $2008.700,000 \mathrm{~m}^{3}$ in 2008 expanded to $3 \mathrm{M} \mathrm{m}^{3}$ in 2009 and reached the maximum storage capacity of $5 \mathrm{M} \mathrm{m}^{3}$ during 2011-2014. The five smaller basins in Neak Pean, the island in the middle of the north Baray are connected to the waters in the Baray and are now full throughout the year. Similarly, west Baray and the Angkor Thom moats are linked via an ancient canal inside the moat. As full-storage capacity of the west Baray was restored, it has been possible to keep Angkor Thom moat full throughout the year.

When the east Baray and the Lolei Baray are fully restored, the water holding capacity of all the Barays, moats and other smaller basins and structures will be more than $110 \mathrm{M} \mathrm{m}^{3}$. Even without the help of east and Lolei Barays, APSARA effectively mitigated the flood threat to the Siem Reap city and its immediate environs during 2012. APSARA estimates that during the rainy season of 2012, it diverted nearly $20 \mathrm{M} \mathrm{m}^{3}$ of flood waters which would have otherwise inundated large parts of the Siem Reap city and its environs. Sixteen $\mathrm{M} \mathrm{m}^{3}$ were drained into the west Baray and $2 \mathrm{M} \mathrm{m}^{3}$ into the north Baray, respectively. The remaining $2 \mathrm{M} \mathrm{m}^{3}$ were dispersed across Angkor Thom and Angkor Wat moats.

APSARA engineers believe that the stability of
Angkor monuments is closely associated with maintenance of ground water at sufficient levels to prevent excessive drying up of the sandy clay soils on which the foundations of many of the monuments rest. Excessive drying and cracking of the soils could lead to collapse of the monuments. Hence, managing the circulation of water within the Angkor hydraulic system, especially during the dry season months from October to April will become as crucial as during the wet season when minimizing flood-threat is the primary concern. As referred to earlier, decades long droughts are thought to have been the cause that triggered events that led to the demise of Angkor in the 14th and 15th centuries [16]. But supporting evidence that would confirm a higher incidence of collapse of monuments during that historical period is lacking. Work now underway using Synthetic Aperture Radar (SAR) technologies under an APSARA/International Centre on Space Technologies for Natural and Cultural Heritage (HIST) of China project will provide more insights into the relationships between groundwater levels, land-subsidence risks and vulnerabilities and stability of monuments.

\section{Forests, People and Institutional Arrangements}

Kulen mountains (Phnom Kulen or the "mountain of lychees") is the birthplace of the Khmer empire [22, 23]. The Cambodian Government has the intention to nominate "Sites of Kulen" as a separate World Heritage site in the future. However, no part of Kulen Mountains was included in the nomination of Angkor Wat in 1991 that was included in the List in 1992.

Phnom Kulen is a sacred mountain and has several archaeological sites that are well known but much less visited than the monuments within the Angkor site as shown in Fig. 1. More recently, Phnom Kulen National Park has become the focus of a range of biodiversity conservation and restoration efforts. A recent biodiversity assessment of the Park revealed 
several interesting findings, for example, the first sighting of the Burmese python (Python vittatus) within the Park was reported [24]. Seven IUCN red-listed amphibian and reptile species, including the Mekong snail-eating turtle (Malayemys subtrijuga) and the elongated Tortoise (Indotestudo elongata) were sighted, mammal species of international concern, namely Pileated Gibbons, Indochinese Silver Langur and Bengal Slow Loris inhabit the Park and the number of wild plant species within the Park was estimated to be 775 .

Twenty-five percent of the Park has been estimated to be forested based on Landsat images [24]. A more recent analyses based on LANDSAT, SPOT and Chinese satellite images of the southern slopes of Kulen mountains (an area of 1,663 $\mathrm{km}^{2}, 40 \mathrm{~m}$ above sea-level and higher, Fig. 6) undertaken by APSARA and HIST of China, under a project entitled "Remote Sensing for Environment of Angkor site (REAS)" has revealed that $35 \%$ of the area is still under forest.
There is a south-north gradient in increasing deforestation. Rates of deforestation were at least 1.5 times higher during the period 2000-2014 in comparison to that of 1989-2000. Reforestation was evident only in about 5\% of the area shown in Fig. 6. In comparison to the deforestation rates in the area shown in Fig. 6, deforestation around the Siem Reap city (the pie-chart in Fig. 3) seems to have been more significant. The return of peace and normalcy to the country increased visitation to Angkor and the urbanization in and around Siem Reap city. Between 1989 and 2009, 30\% of forested area in a $138 \mathrm{~km}^{2}$ tract in and around the city shown in Fig. 3 was urbanized. Urbanization of croplands was even more intense, i.e. $42 \%$ of croplands were converted to urban use.

In 2010, the $400 \mathrm{~km}^{2}$ Angkor World Heritage area contained 112 villages and a total population of 120,000 inhabitants. Another study conducted in 2007 estimated the per capita income of the population to

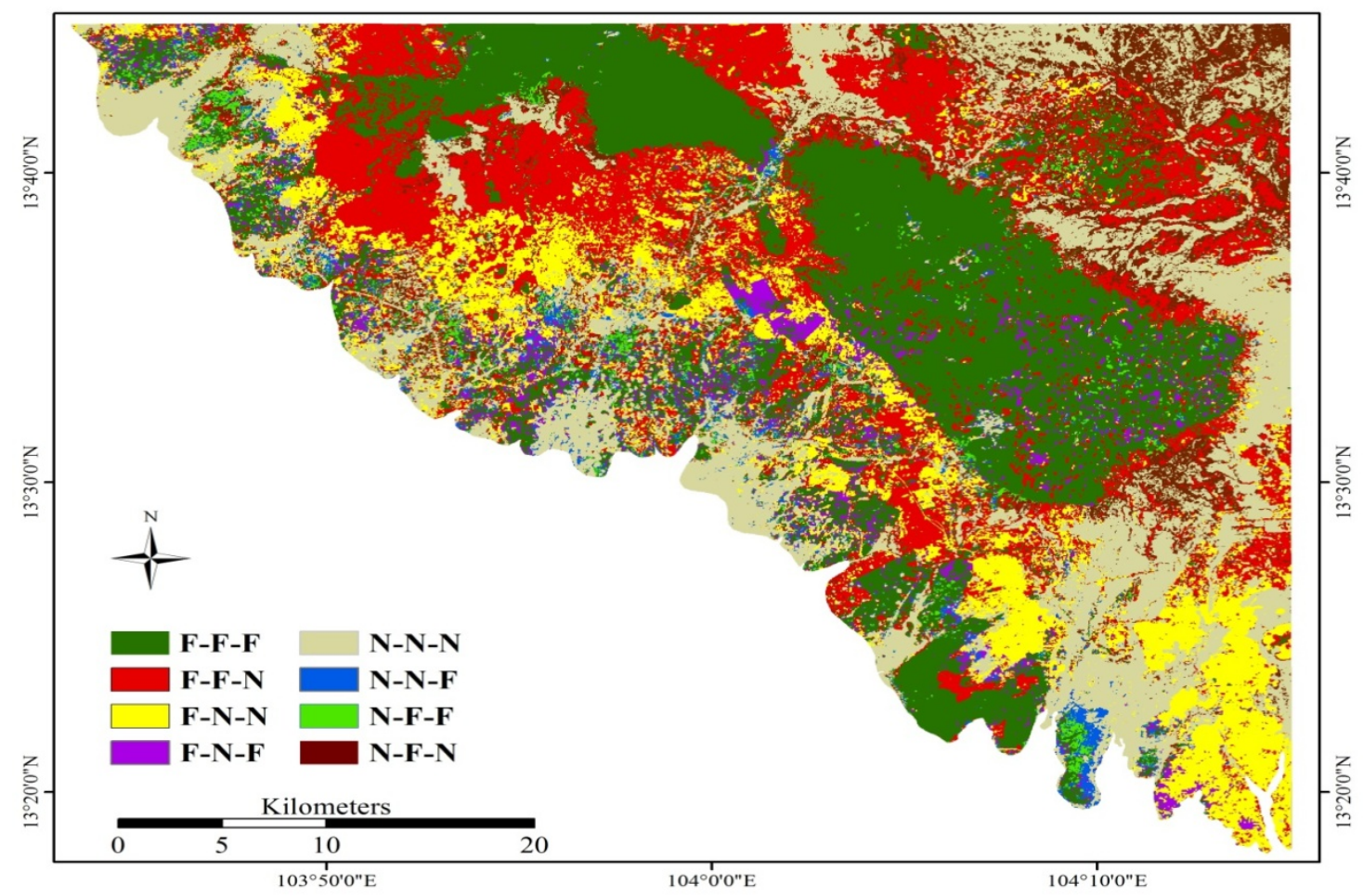

Fig. 6 Forest cover changes in Kulen Mountains from 1989 to 2014, $F$ refers to forested and $N$ to non-forested areas; the legend from F-F-F to N-F-N indicate directions of change (or the lack of it); the total area mapped and analyzed in the southern slope of the Kulen Mountains is $1,663 \mathrm{~km}^{2}$. 
be 24-30 US\$, far below present international limits of poverty. A 2007 Angkor Management Plan, a 2010 Angkor Heritage Management Framework and other tools like risk maps for the World Heritage site are now being integrated into a new Management Plan which assigns significant priority to the needs of local communities. APSARA has pursued participatory approaches for natural resources management and livelihood planning to develop a number of pilot projects. Examples include the Run Ta-Ek ecovillage and community-level tourism planning and implementation. Several others are foreseen for implementation in the near future [25]. Engaging local communities in management and improving their socio-economic status is a favoured strategy to link conservation and sustainable development in many other cultural World Heritage sites too [26, 27].

The benefits that Angkor tourism development and planning has brought to local communities had been questioned by an earlier study that has argued that the conservation of Angkor World Heritage site excluded local inhabitants from their social space [28]. Re-thinking old conservation approaches and the introduction of new ways to develop Angkor as a living heritage is gaining greater attention now [28]. APSARA has commissioned research and development projects on intangible heritage to allow for the continuing practice of monastic life-styles and to permit villagers to worship their favourite deities within the World Heritage site. Engagement of the local communities in planning and implementing agricultural and water management activities are increasingly preferred to top-down decrees [25].

APSARA's effectiveness has been significantly strengthened by the International Coordinating Committee (ICC) of Angkor, established almost at the same time as the inscription of the site in 1992 [29]. Jointly Chaired by France and Japan, the ICC has been an interlocutor between APSARA and the Cambodian Government on one hand and the Committee and international partners and donors on the other. Through twice-a-year meetings, ICC reviews work undertaken by APSARA and its international partners and sets priorities for future collaboration. As the Committee raised conservation-sustainable development links as a priority for implementation during the Convention's fifth decade [4], the ICC ensured the immediate integration of that priority into the work of APSARA and its international donors and partners at the national and site levels.

\section{Sustainable Development of the Angkor Ecosystem-The Next Decade}

At the twentieth technical session of ICC-Angkor, Dr. Jean Marie Le Furt [30] reporting on sustainable development noted: "The second component after time is space. One must think on a wider scope, but not to relocate the problems. Think wider...... I believe, there is the need to come out of a perspective only focusing on the site...... To think wider will take some time because there is red tape; there are operating modes which do not allow changing gear straight away. To think wider.......about the town at the same time, not at a later time. Think about things simultaneously......think about a larger territory that could include the site, the city......think about the Tonle Sap lake".

The recognition of the importance of the hydraulics of Angkor has widened thinking of the management from site to ecosystem scales. The watersheds of the three main rivers (Fig. 1) cover an area 7 times the size of the World Heritage site. The APSARA-HIST Project, REAS, referred to earlier aims to build a spatial database and 3D simulation and GIS models (Fig. 7) for an even larger $\left(5,000 \mathrm{~km}^{2}\right)$ area including the watersheds and additional areas west and east of them. Sustainable development must inevitably extend beyond the spatial scale of World Heritage sites and planning and management must integrate site-conservation priorities into territorial and regional development strategies. However, integrating 


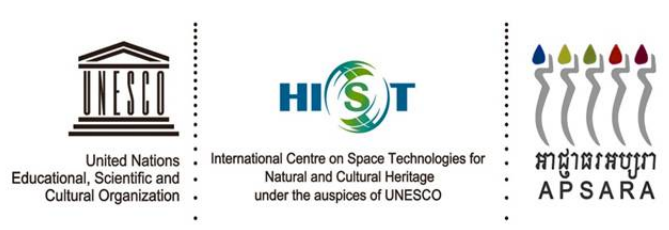

\section{Remote Sensing for Environment of Angkor Site (2013-2015)

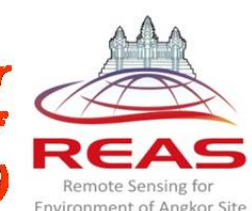

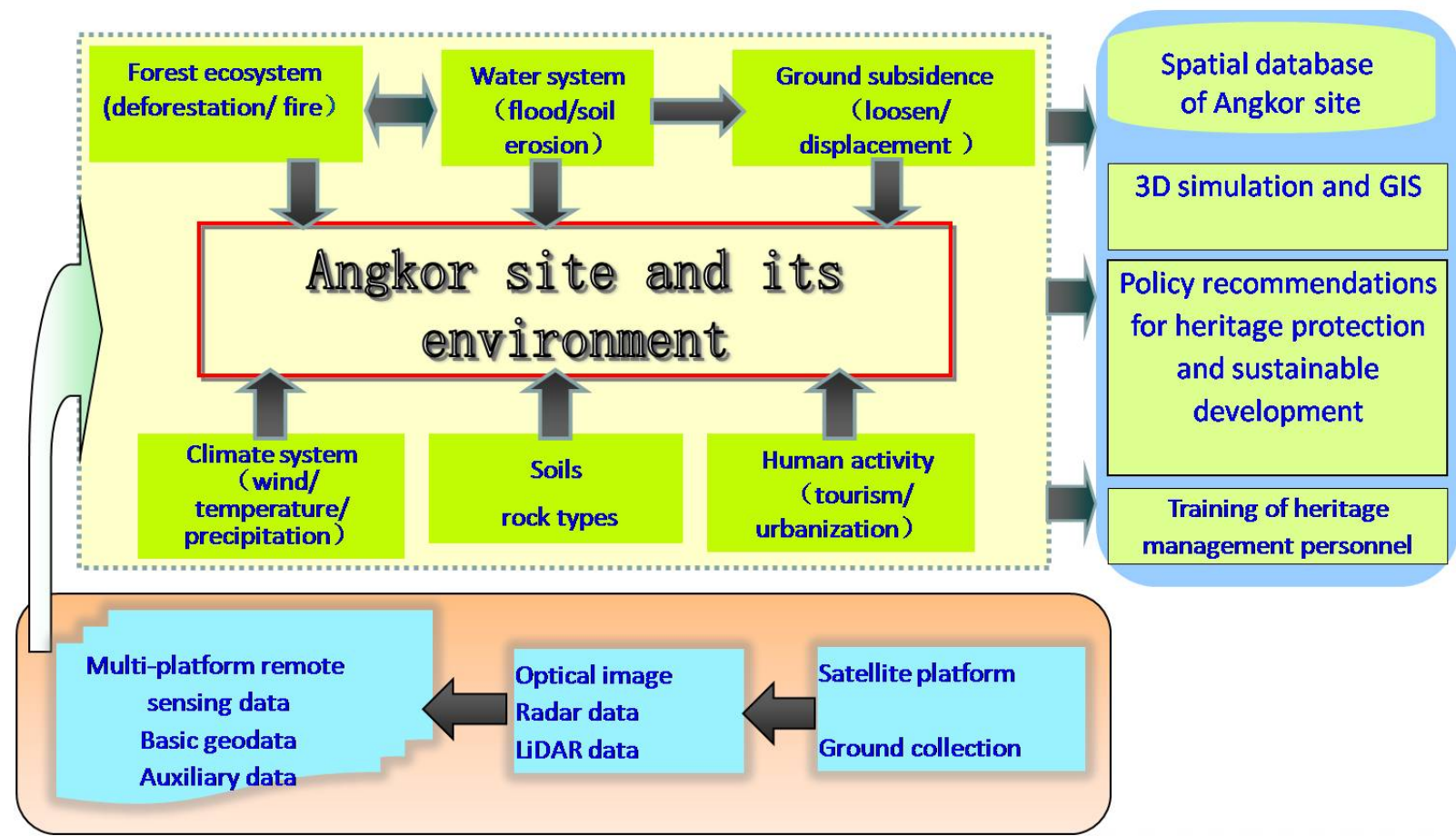

Fig. 7 Design of the APSARA-HIST Project on "Remote Sensing for Environment of Angkor Site (REAS)" for the period 2013-2016.

conservation areas to sustainable development of larger regions and territories is easier said than done. In this regard, the experience of another category of UNESCO designated place, the World Biosphere Reserve may provide insights and lessons [31]. Difficulties in achieving conservation-development integration in biosphere reserves have been analysed $[32,33]$. Institutional co-ordination and co-operation have been major constraints in integrating biodiversity conservation into regional and territorial planning in both developed and less developed countries [34, 35].

APSARA is more and more successful in integrating conservation and economic development in the immediate vicinity of the World Heritage site. The future challenge to APSARA is to become capable of influencing economic, environmental and social planning and implementation in the whole of the Angkor ecosystem as visualized in this paper (Figs. 1 and 2). Integrating Mt. Kulen into the Angkor World Heritage site is a step that generates heated debates within APSARA and the international support community who are active participants within the ICC. Such a move will favourably impact APSARA's influence to guide heritage conservation and socio-economic development over the entire Angkor ecosystem. But other existing land and resource use management agencies may resist such an expansion of APSARA's authority and influence. Greater co-ordination of economic, environmental and social development of areas between the current boundaries of the World Heritage site and Mt. Kulen, about 40 $\mathrm{km}$ northeast of the site, will become increasingly critical to the sustainable development of the overall Angkor ecosystem. Tourism infrastructure 
development in areas between the World Heritage site and Mt. Kulen is currently sparse. Targeting those areas for future development could spread visitor access and facilities away from the Siem Reap city and distribute the benefits of the hospitality sector to new locations and beneficiaries. Mt. Kulen as the place of origin of the Khmer Empire that reached its pinnacle in Angkor can be integrated into the presentation of Angkor to visitors and the public. But such a move would require consensus and co-operation of a number of land and resource use management agencies who are currently peripheral to the management of the World Heritage site. In biosphere reserves of Vietnam, the most important constraint to effective integration of planning and actions across conservation and development zones was institutional coordination and cooperation [36].

Tonle Sap as a source of water to meet the modern-day demands of residents and visitors within the ecosystem is likely to attract greater attention in the future. As awareness of the potentially delicate relationship between ground water levels and monument stability within the Angkor ecosystem has grown there is recognition that sooner than later the current, unhindered rates of extraction of groundwater within the Angkor ecosystem would have to be regulated and preferably abandoned over the long-term. The Siem Reap city and its environs where tourism and hospitality sector infrastructure are concentrated are most dependent on groundwater sources at present. Given that the city is situated in the drainage zone of the watersheds of the Pourk, Siem Reap and Rolous rivers (Figs. 1 and 2), the possibility of using lake waters to supply the needs of the city merits serious consideration. A feasibility study sponsored by the Japanese International Co-operation Agency (JICA) is investigating this option.

Linking World Heritage and sustainable development would require integrating natural and cultural heritage of the broader landscape surrounding World Heritage sites [37]. Although ecosystem and species characteristics of the Angkor ecosystem may not meet OUV standards as currently defined and interpreted by natural heritage experts [38], they are nevertheless of significance to demonstrating an ecosystem approach to conservation and sustainable use of biodiversity as advocated under the Convention on Biological Diversity ratified by 194 States including Cambodia [39]. The ecosystem approach has in particular found favour in watershed and integrated water resources management and the conservation and management of the Angkor ecosystem as envisaged in this paper (Figs. 4 and 5) could make an interesting case of research and application to this theme of worldwide interest [40]. To-date, ecosystem based management approaches are more frequent in World Natural than in Cultural Heritage sites [41].

The Millennium Ecosystem Assessment [42] for assessing the consequences of ecosystem change for human well-being identified four sets of ecosystem services: supporting, provisioning, regulating and cultural. Managing water flow and storage regimes in the Barays, moats and other structures have an important flood regulation function within the Angkor ecosystem. Through its influence on soil properties that in-turn impact monument stability, effective water management is critical for long-term maintenance of OUV of the Angkor World Heritage site.

Cultural ecosystem services refer to the ensemble of aesthetic, spiritual, educational and recreational services provided by ecosystems. They constitute a growing field of research applied to landscapes and natural ecosystems [43-45]. Yet, the application of the cultural ecosystem services approach to analysing cost-benefit ratios and outcomes of tourism and hospitality sector in World Heritage sites has been rare. The Angkor ecosystem could be an interesting case study for initiating such collaboration between ecosystem services and cultural landscapes research communities.

The transition of the management of Angkor World Heritage of Cambodia from the conservation of an 
archaeological park to sustainable development of an ecosystem provides unique opportunities for exploring the role of cultural ecosystem services as a research tool that could facilitate the strategic shift. More than 20 years of work of APSARA and its national and international partners have accumulated data on quantitative and tangible (heritage tourism, hospitality and recreation) as well as on qualitative and intangible (education and awareness of history, culture and identity) aspects of cultural services provided by the Angkor ecosystem. The information and insights expressed in this paper could trigger efforts to study and analyse the Angkor ecosystem as a provider of cultural ecosystem services, with a view to using the benefits provided by those services for the sustainable development of the Angkor ecosystem and the broader Siem Reap province.

The concept of sustainable development, as currently understood, is barely 30 years old. Original contradictions arising from its multi and inter-disciplinary character have been tamed and the concept has now come of age [46, 47]. Attempts to experiment with sustainable development by policy, planning and management practitioners have progressed in parallel and may have at times outpaced or diverged from interests and needs of academic and research communities. Similar to observations made with regard tourism studies [48], sustainable development research community is relatively new and may not have kept pace with the dramatic growth in practitioner level experimentation underway in places like the Angkor World Heritage site. Case studies as that presented herein attempt to provide as accurate a description as possible of on-going efforts in order to encourage learning from in-situ sustainable development practice. As observed by Forester, J. [49], insightful practice can lead theoretical construction and synthesis, particularly in planning and policy studies. The case study description provided in this paper could form a baseline for future studies that can attempt to monitor progress in integrating the conservation of World Heritage sites and the management of ecosystem components that are outside of sites. Pursuit of research on the tourism and hospitality sector under a cultural ecosystem services framework should be encouraged and accelerated as an aid to a better understanding and application of the ecosystem approach to the sustainable development of the Angkor ecosystem. Experience in Angkor may trigger interest in adopting cultural ecosystem services approach to the pros and cons of the development of the tourism and hospitality sector in many other World Heritage sites.

\section{Conclusions}

Of the 17 SDGs adopted by the United Nations in September 2015, SDG 11 aims to "make cities and human settlements inclusive, safe, resilient and sustainable". One of the targets (target 11.4) that would satisfy the attainment of SDG 11 is to strengthen efforts to safeguard the world's cultural and natural heritage. Another one of the SDG 11 targets is to support "positive economic, social and environmental links between urban, peri-urban and rural areas by strengthening national and regional development planning".

The shift of focus of Angkor management from conservation and restoration of monuments within the archaeological Park to the sustainable development of the Angkor ecosystem presents an opportunity for demonstrating the role of Angkor in attaining SDG 11 in Cambodia. The two targets above could be the basis to derive appropriate metrics to measure and monitor progress. The development of the Siem Reap city and province and that of the rural hinterlands of the Angkor ecosystem between the World Heritage site and Mt. Kulen are intricately linked with the conservation of OUV of the World Heritage site. The sustainable development of the tourism and hospitality sector, entirely dependent on the cultural ecosystem services provided by the Angkor ecosystem, is critical to the long-term maintenance of OUV of the Angkor World Heritage site. 
The social, economic and environmental contiguity between sustainability of urban, peri-urban and rural spaces, difficult to track in the world's mega cities, are still evident in the Angkor ecosystem with Siem Reap city as the most urbanized space. The distance separating this city and its environs and the rural and semi-natural hinterlands along the southern foothills of Mt. Kulen is only about $50 \mathrm{~km}$. Within such a realistic distance in this virtual age lies humanity's precious heritage of Angkor. As sustainable development of the Angkor ecosystem described in this paper moves forward, bringing together the boundaries and identities of the Angkor World Heritage and Angkor ecosystem is a worthy goal for APSARA and its national and international partners to pursue.

\section{References}

[1] UNESCO. 1972. Convention Concerning the Protection of the World Cultural and Natural Heritage. Paris, France: UNESCO.

[2] UNESCO. 2013. Operational Guidelines for the Implementation of the World Heritage Convention. Paris: World Heritage Centre.

[3] World Commission on Environment and Development (WCED). 1987. Our Common Future. Oxford: Oxford University Press.

[4] UNESCO. 2013. "Celebrating 40 Years of the World Heritage Convention." In Proceedings of the Closing Event of the Celebration of the 40th Anniversary, UNESCO, Paris, 238.

[5] Nicolay, S., Hoy, C., Berliner, T., and Aedy, T. 2015. Projecting Progress: Reaching the SDGs by 2030. London, UK: Overseas Development Institute (ODI).

[6] Larsen, P. B., and Wijesuriya, G. 2015. Nature-Culture Interlinkages in World Heritage: Bridging the Gap. Paris: World Heritage Centre.

[7] UNESCO. 1992. Report of the Rapporteur of the Sixteenth Session of the World Heritage Committee. Paris: World Heritage Centre .

[8] IUCN. 1982. The World's Greatest Natural Areas, An Indicative Inventory of Natural Sites of World Heritage Quality. Switzerland: International Union for Conservation of Nature and Natural Resources.

[9] UNESCO. 1980. Operational Guidelines for the Implementation of the World Heritage Convention. Paris: World Heritage Centre.

[10] Mishra, H., and Ishwaran, N. 1992. "Summary and conclusions of the workshop on the World Heritage Convention." In World Heritage: Twenty Years Later. Report of the World Heritage and Other Workshops Held during the IVth World Parks Congress on National Parks and Protected Areas, Caracas, Venezuela. IUCN, Gland, Switzerland, 13-18.

[11] Rossler, M. 2006. "World Heritage Cultural Landscapes, UNESCO Flagship Programme." Landscape Research 31 (4): 333-53.

[12] Cameron, C., and Rossler, M. 2013. Many Voices, One Vision: The Early Years of the World Heritage Convention. UK: Ashgate Publishers.

[13] Peou, Hang. 2013. "The Angkorean Hydraulic System." World Heritage 68 (June): 24-27.

[14] Kummu, M. 2003. "The Natural Environment and Historical Water Management of Angkor, Cambodia." Presented at the 5th World Archaeological Congress.

[15] Fletcher, R., Penny, D., Evans, D., Pottier, C., Barbetti, M., and Kummu, M. et al. 2007. "The Water Management Network of Angkor, Cambodia." ANTIQUITY 82: 658-670.

[16] Buckley, B. M., Anchukaitis, K. J., Penny, D., Fletcher, R., Cook, E. R., and Sano, M. et al. 2010. "Climate as a Contributing Factor in the Demise of Angkor, Cambodia." In Proceedings of the National Academy of Sciences 107 (15): 6748-6752.

[17] Reid, A. 1988. Southeast Asia in the Age of Commerce, 1450-1680. New Haven: Yale University Press.

[18] Stone, R. 2006. "The End of Angkor." Science 311: 1364-1368.

[19] Wade, G. 2009. "An Early Age of Commerce in Southeast Asia, 900-1300CE." Journal of Southeast Asian Studies 40 (2): 221-265.

[20] Pottier, C. 1999. "Archaeological Map of the Angkor Area-Southern Zone." Ph.D. thesis, Sorbonne University.

[21] Evans, D., Fletcher, R., and Suy, Tan Boun. 2013. "2012 LiDAR Survey over Angkor, Phnom Kulen and Koh Ker." World Heritage 68: 62-65.

[22] Higham, C. 2003. The Civilization of Angkor (1st Ed.). UK: Phoenix Paperback.

[23] Rooney, D. F. 2005. Angkor: Cambodia's Wondrous Khmer Temples (5th Ed.). Cambodia: Odissey.

[24] Hayes, B., Mould, A., Khou, E. H., Hartmann, T., Hoa, K., and Calame, T. et al. 2013. A Biodiversity Assessment of Phnom Kulen National Park with Recommendations for Management. Cambodia: Angkor Centre for Conservation of Biodiversity.

[25] Khoun, K.-N. 2012. "Angkor Archaeological Park and Communities: Angkor, Cambodia." In World Heritage, Benefits Beyond Borders, 312-324, edited by Amareswar, G. UK: UNESCO Paris and Cambridge University Press. 
[26] Galla, A. 2012. "World Heritage in Poverty Alleviation: Hoi an Ancient Town, Vietnam." In World Heritage, Benefits Beyond Borders, 107-120, edited by Amareswar, G. UK: UNESCO Paris and Cambridge University Press.

[27] Pessis Anne-Marie Guidon, N., and Martin, G. 2012. "World Heritage in Poverty Alleviation: Serra de Capivara National Park, Brazil." In World Heritage, Benefits Beyond Borders, 301-311, edited by Amareswar, G. UK: UNESCO Paris and Cambridge University Press.

[28] Miura, K. 2005. "Conservation of a "Living Heritage": A Contradiction of Terms? A Case Study of Angkor World Heritage Site." Conservation and Management of Archaeological Sites 7 (1): 3-18.

[29] UNESCO. 2008. ICC-Angkor, 15 Years of International Cooperation for Conservation and Sustainable Development. UNESCO Cambodia: Phnom Penh.

[30] UNESCO. 2011. Lecture (Report) of the Twentieth Technical Committee-ICC-Angkor. UNESCO Cambodia: Phnom Penh.

[31] Ishwaran, N. 2012. "Science in Intergovernmental Environmental Relations: 40 Years of UNESCO's Man and the Biosphere (MAB) Programme and Its Future." Environmental Development 1: 91-101.

[32] Ishwaran, N., Persic, A., and Tri, N. H. 2008. "Concept and Practice: The Case of UNESCO Biosphere Reserves." International Journal of Environment and Sustainable Development 7 (2): 118-131.

[33] Ishwaran, N. 2010. "Biodiversity, People and Places." Australasian Journal of Environmental Management 17 (January): 215-222.

[34] Thomas, C. W. 2003. Bureaucratic Landscapes: Interagency Cooperation and the Preservation of Biodiversity. Cambridge: The MIT Press.

[35] Wells, M., Guggenheim, S., Khan, A., Wardojo, W., and Jepson, P. 1999. Investing in Biodiversity: A Review of Indonesia's Integrated Conservation and Development Projects. Washington DC: The World Bank.

[36] Nguyen, N. C., Bosch O. J. H., and Maani, K. E. 2010. "Creating "Learning Laboratories" for Sustainable Development in Biospheres." Systems Research and Behavioral Science 28 (1): 51-62. doi:10.1002/sres.1044.

[37] Rao, K. 2012. "Pathways to Sustainable Development." In World Heritage, Benefits Beyond Borders, 325-331, edited by Amareswar, G. UK: UNESCO, Paris and
Cambridge University Press.

[38] IUCN. 2013. Terrestrial Biodiversity and the World Heritage List, Identifying Broad Gaps and Potential Candidate Sites for Inclusion in the Natural World Heritage Network. Gland, Switzerland: IUCN.

[39] UN. 1992. The Convention on Biological Diversity. Canada: Secretariat of the Convention on Biological Diversity (CBD).

[40] Parkes, M. W., Morrison, K. E., Bunch, M. J., and Venema, H. D. 2008. Ecohealth and Watersheds: Ecosystem Approaches to Re-integrate Water Resources Management with Health and Well-Being. Canada: Network for Ecosystem Sustainability and Health.

[41] Miyazawa, Y., and Makino, M. 2012. "Role of Fisheries and Ecosystem Management: Shiretoko, Japan.” In World Heritage, Benefits Beyond Borders, 253-263, edited by Amareswar, G. UK: UNESCO, Paris and Cambridge University Press.

[42] Millenium Ecosystem Assessment. 2005. Ecosystem Services and Human Well Being: Synthesis. Washington DC: Island Press.

[43] Milcu, A. I., Hanspach, J., Abson, D., and Fischer, J. 2013. "Cultural Ecosystem Services: A Literature Review and Prospects for Future Research." Ecology and Society 18 (3): 44.

[44] Tengberg, A., Fredholm, S., Eliasson, I., Knez, I., Saltzman, K., and Wetterberg, O. 2012. "Cultural Ecosystem Services Provided by Landscapes: Assessment of Heritage Values and Identity." Ecosystem Services 2: 14-26. doi.10.1016/j.ecoser.2012.07.006.

[45] Gould, R. K., Ardoin, N. M., Woodside, U., Satterfield, T., Hannahs, N., and G. C. 2014. "The Forest Has a Story: Cultural Ecosystem Services in Kona, Hawaii.” Ecology and Society 19 (3): 55.

[46] Redclift, M. R. 1987. Sustainable Development: Exploring the Contradictions. London: Routledge.

[47] Redclift, M. 2006. "Sustainable Development (1987-2005): An Oxymoron Comes of Age." Horizontes Antropológicos 12 (25): 65-84.

[48] Franklin, A., and Crang, M. 2001. "The Trouble with Tourism and Travel Theory." Tourist Studies 1 (1): 5-22.

[49] Forester, J. 1999. The Deliberative Practitioner: Encouraging Participatory Planning Processes. Cambridge: MIT Press. 